\title{
Arkadiusz Bereza
}

Uniwersytet Marii Curie-Skłodowskiej w Lublinie

arkadiusz.bereza@poczta.umcs.lublin.pl

\section{Ewolucja statusu radcy prawnego w postępowaniu karnym}

\author{
The Evolution of the Status of Legal Counsel in a Criminal Procedure
}

\section{STRESZCZENIE}

Status radcy prawnego w postępowaniu karnym ulegał z biegiem czasu stopniowej zmianie. Były one uzależnione od czynników politycznych oraz wiązały się z koniecznością przełamania oporu adwokatury. Początkowo radca prawny mógł występować w procesie karnym jako pełnomocnik, choć to uprawnienie było do 2009 r. ograniczone do ściśle określonego kręgu reprezentowanych podmiotów. Uprawnienia obrończe po raz pierwszy, nie licząc postępowań dyscyplinarnych, zostały radcom prawnym przyznane w sprawach o wykroczenia w $2001 \mathrm{r}$. Zbliżenie uprawnień radców prawnych i adwokatów zaowocowało projektem ustawy o zawodzie adwokata z dnia 22 października 2009 r., zmierzającym do stworzenia tzw. nowej adwokatury. Projekt nie został uchwalony ze względu na krytyczne stanowiska obu samorządów. Przewidywał w swej treści możliwość występowania radcy prawnego w charakterze obrońcy w postępowaniu karnym. Realizacja tego postulatu została podjęta w pracach nad wielką nowelizacją postępowania karnego. Prace te rozpoczęły się w 2012 r. i znalazły finał w ustawie z dnia 27 września 2013 r. o zmianie ustawy - Kodeks postępowania karnego i niektórych innych ustaw. Ostatecznie przyznano radcom prawnym uprawnienie do występowania w charakterze obrońcy w postępowaniu karnym, z wyłączeniem radców prawnych pozostających w stosunku pracy, nie licząc pracowników naukowych i naukowo-dydaktycznych. Próby zakwestionowania wskazanej nowelizacji przez adwokaturę przed Trybunałem Konstytucyjnym okazały się nieskuteczne. Kolejna zmiana postępowania karnego, uchwalona w marcu 2016 r., przywracająca niektóre rozwiązania obowiązujące przed wielką reformą procesu karnego, nie zmieniła już wprowadzonych uprawnień radców prawnych do występowania w charakterze obrońcy w postępowaniu karnym.

Słowa kluczowe: radca prawny; postępowanie karne; obrońca; pełnomocnik; pomoc prawna z urzędu 
Radcowie prawni początkowo zajmowali się obsługą prawną państwowych i spółdzielczych jednostek organizacyjnych. Z ich obsługi prawnej mogły korzystać także organizacje społeczne oraz spółki z udziałem kapitału państwowego, spółdzielczego lub organizacji społecznych ${ }^{1}$. Zasadą było wykonywanie zawodu w stosunku pracy, ale możliwe było skorzystanie z doraźnej pomocy prawnej w oparciu o umowę zlecenia ${ }^{2}$.

W związku z pierwotnym brzmieniem ustawy o radcach prawnych i wcześniej wykonywanymi czynnościami radców prawnych zatrudnionych w różnych jednostkach organizacyjnych pozostają oni w świadomości społecznej jako osoby zapewniające obsługę prawną obrotu gospodarczego oraz organów władzy publicznej. Tak pozostało do dziś, mimo rozszerzenia zakresu świadczenia pomocy prawnej przez radców prawnych na rzecz osób fizycznych.

$\mathrm{Z}$ czasem pojawiały się nowe uprawnienia radców prawnych oraz formy wykonywania tego zawodu. Proces powiększenia katalogu form wykonywania zawodu rozpoczął się wraz ze zmianami społeczno-gospodarczymi w Polsce po 1989 r. i nabrał przyspieszenia po 1996 r. Poszerzanie uprawnień radców prawnych natomiast było uzależnione od czynników politycznych, a uchwalenie jakichkolwiek zmian w tym zakresie niosło za sobą konieczność przełamania oporu adwokatury, dostrzegającej zagrożenie dla zmonopolizowanych przez nią sfer świadczenia pomocy prawnej.

Prowadziło to do chaosu związanego z konstruowaniem przepisów będących efektem zawieranych kompromisów w trakcie prowadzonych prac legislacyjnych. Ponadto zmiany, jakie przeprowadzano po 1996 r., nie były przykładem dobrej legislacji. Wynikało to $\mathrm{z}$ faktu, że wprowadzone zmiany samodzielnie nie stanowiły podstawy do określenia zakresu, $w$ jakim radca prawny może występować w charakterze pełnomocnika w postępowaniu sądowym.

Uchwaleniu ustawy - Kodeks postępowania karnego z dnia 6 czerwca 1997 r. ${ }^{3}$ nie towarzyszyła odpowiednia zmiana ustawy o radcach prawnych, dotycząca zakresu świadczonej pomocy prawnej. W ten sposób dochodziło do niespójności systemowej prawa, braku możliwości egzekwowania przez radców prawnych nowych przepisów w praktyce sądowej oraz konieczności przeprowadzenia stosownej zmiany powiązanej w ustawie o radcach prawnych. Nastąpiło to dopiero 10 września 1999 r. ${ }^{4}$ Analogicznie, wprowadzając zmiany w ustawie o radcach prawnych

\footnotetext{
${ }^{1}$ Art. 4 ust. 1 i ust. 2 ustawy z dnia 6 lipca 1982 r. o radcach prawnych (Dz.U., nr 19, poz. 145), dalej jako: u.r.p.

2 Art. 8 ust. 1 i 20 u.r.p.

${ }^{3}$ Ustawa z dnia 6 czerwca 1997 r. - Kodeks postępowania karnego (Dz.U., nr 89, poz. 555), dalej jako: k.p.k.

${ }^{4}$ Ustawa z dnia 10 września 1999 r. - Kodeks karny skarbowy (Dz.U., nr 83, poz. 930), zmieniająca również art. 4 ust. $1 \mathrm{zd} .2$ ustawy o radcach prawnych.
} 
(ustawą z dnia 30 czerwca 2005 r. ${ }^{5}$ ), zapomniano o związanych z nimi zmianach w k.p.k. Wprowadzono je dopiero 5 listopada $2009 \mathrm{r}^{6}$

Radca prawny w postępowaniu karnym mógł w tym okresie występować jedynie jako pełnomocnik. Art. 88 k.p.k. w brzmieniu z 1997 r. wskazywał, że pełnomocnikiem instytucji państwowej, samorządowej lub społecznej mógł być radca prawny albo inny pracownik tej instytucji lub jej organu nadrzędnego. Natomiast w zakresie roszczeń majątkowych pełnomocnikiem osoby prawnej, innej niż wyżej wskazana, jednostki organizacyjnej niemającej osobowości prawnej, a także osoby fizycznej prowadzącej działalność gospodarczą mógł być również jej radca prawny. Po wejściu w życie ustawy - Kodeks karny skarbowy z dnia 10 września w 1999 r. radca prawny mógł występować także w charakterze pełnomocnika w sprawach o przestępstwa skarbowe i wykroczenia skarbowe?

Art. 88 k.p.k., pod wpływem wątpliwości, jakie pojawiały się na tle jego stosowania, uległ zmianie z dniem 1 lipca $2003 \mathrm{r}^{8}$ Pozostawiono jednak dotychczasowe ograniczenia kręgu podmiotów reprezentowanych przez radcę prawnego - pełnomocnika w procesie karnym. Na ich zniesienie przyszło poczekać prawie 7 lat.

Radcowie prawni po raz pierwszy (pomijając postępowania dyscyplinarne) uprawnienia do występowania w charakterze obrońcy otrzymali w postępowaniu w sprawach o wykroczenia. Taką możliwość przewidywała ustawa z dnia 24 sierpnia 2001 r. - Kodeks postępowania w sprawach o wykroczenia9. Przed wejściem w życie tej ustawy postępowanie w sprawach o wykroczenia mogło toczyć się przed kolegiami do spraw wykroczeń oraz przed sądami. Przed sądami obrońcą mógł być tylko adwokat, natomiast przed kolegiami także osoba godna zaufania i dopuszczona przez przewodniczącego kolegium lub składu orzekającego, a w szczególności przedstawiciel związku zawodowego lub innej organizacji społecznej, której członkiem był obwiniony ${ }^{10}$. Obrońcą w takim przypadku mógł być więc również radca prawny, jednak była to tzw. obrona społeczna.

Warto zaznaczyć, że pierwotna wersja projektu ustawy - Kodeks postępowania w sprawach o wykroczenia przewidywała odpowiednie stosowanie do obroń-

${ }^{5}$ Ustawa z dnia 30 czerwca 2005 r. o zmianie ustawy - Prawo o adwokaturze, ustawy o radcach prawnych i ustawy o notariacie (Dz.U., nr 163, poz. 1361).

${ }^{6}$ Ustawa z dnia 5 listopada 2009 r. o zmianie ustawy - Kodeks karny, ustawy - Kodeks postępowania karnego, ustawy - Kodeks karny wykonawczy, ustawy - Kodeks karny skarbowy oraz niektórych innych ustaw (Dz.U., nr 206, poz. 1589).

7 Art. $123 \S 1$ ustawy z dnia 10 września 1999 r. - Kodeks karny skarbowy (Dz.U., nr 83, poz. 930), dalej jako: k.k.s.

${ }^{8}$ Ustawa z dnia 10 stycznia 2003 r. o zmianie ustawy - Kodeks postępowania karnego, ustawy - Przepisy wprowadzające Kodeks postępowania karnego, ustawy o świadku koronnym oraz ustawy o ochronie informacji niejawnych (Dz.U., nr 17, poz. 155).

${ }^{9}$ Art. 24 ustawy z dnia 24 sierpnia 2001 r. - Kodeks postępowania w sprawach o wykroczenia (Dz.U., nr 106, poz. 1148).

${ }^{10}$ Art. 30 § 1 ustawy z dnia 20 maja 1971 r. - Kodeks postępowania w sprawach o wykroczenia (Dz.U., nr 12, poz. 116). 
cy w postępowaniu w sprawach o wykroczenia przepisów kodeksu postępowania karnego $^{11}$, co oznaczałoby przyznanie prawa do występowania $\mathrm{w}$ charakterze obrońcy jedynie adwokatom. Przepis ten w trakcie procesu legislacyjnego został poddany krytyce, w ramach której uwzględniono postulat Krajowej Rady Radców Prawnych (KRRP) - w opozycji do Naczelnej Rady Adwokackiej (NRA) - przyznania tych uprawnień obrończych także radcom prawnym ${ }^{12}$. W ślad za tymi zmianami ustawa z dnia 28 lipca 2005 r. o zmianie ustawy - Kodeks karny skarbowy umożliwiła radcom prawnym występowanie w charakterze obrońców w postępowaniu o wykroczenia skarbowe ${ }^{13}$.

Poza zakresem pomocy prawnej świadczonej przez radców prawnych pozostawała jedynie rola obrońcy w postępowaniu karnym i w postępowaniu w sprawach o przestępstwa skarbowe, co wyraźnie precyzował art. 4 ust. 1 u.r.p. po wejściu w życie ustawy z dnia 30 czerwca 2005 r. o zmianie ustawy - Prawo o adwokaturze, ustawy o radcach prawnych i ustawy o notariacie ${ }^{14}$.

Uprawnienia adwokatów i radców prawnych znacznie zbliżyły się do siebie. To dało asumpt do prac nad połączeniem dwóch samorządów prawniczych. Duże emocje wywołały założenia do projektu ustawy o zawodzie adwokata z dnia 22 października 2009 r., przygotowane w Ministerstwie Sprawiedliwości ${ }^{15}$. Twórcy założeń podkreślali, że zawody radcy prawnego i adwokata mają spełniać te same zadania w systemie ochrony prawnej, a istnienie obecnie dwóch odrębnych zawodów i samorządów wynika jedynie z uwarunkowań historycznych. Połączenie miało prowadzić do stworzenia tzw. nowej adwokatury. Związane z tym było rozszerzenie uprawnień do występowania $\mathrm{w}$ charakterze obrońcy w postępowaniu karnym na dotychczasowych radców prawnych, z jednoczesnym wprowadzeniem stosunku pracy jako dodatkowej formy wykonywania zawodu adwokata.

Projekt stał się przedmiotem debaty środowiskowej i uchwał organów samorządów prawniczych. Z różnych przyczyn Krajowy Zjazd Radców Prawnych oraz Krajowy Zjazd Adwokatury odniosły się krytycznie do przedstawionych założeń ${ }^{16}$. Do tych stanowisk został dołączony ostry sprzeciw samorządów prawniczych wobec niektórych postanowień projektu ustawy o państwowych egzaminach prawniczych (jak np. nadanie magistrom prawa uprawnienia do występowania przed sądem

\footnotetext{
${ }^{11}$ Art. 24 projektu ustawy - Kodeks postępowania w sprawach o wykroczenia (druk nr 2465).

12 A.R. Światłowski, Radca prawny jako obrońca $w$ postępowaniach $w$ sprawach o wykroczenia, „Radca Prawny” 2002, nr 2, s. 6-7.

${ }_{13}$ Art. 122a k.k.s. dodany przez art. 1 pkt 97 ustawy z dnia 28 lipca 2005 r. (Dz.U., nr 178, poz. 1479).

${ }^{14}$ Art. 4 ust. 1 ustawy o radcach prawnych, zmieniony przez art. 2 pkt 1 ustawy zmieniającej z dnia 30 czerwca 2005 r. (Dz.U., nr 163, poz. 1361).

15 Projekt założeń z dnia 22 października 2009 r. do projektu ustawy o zawodzie adwokata.

${ }^{16}$ Uchwała Nadzwyczajnego Krajowego Zjazdu Radców Prawnych nr 1/2010 z dnia 27 lutego 2010 r. w sprawie stanowiska samorządu radców prawnych co do prowadzonych prac legislacyjnych dotyczących zawodów prawniczych.
} 
w sprawach należących do właściwości sądów rejonowych), który był systemowo powiązany z wizją ,nowej adwokatury”, co ostatecznie doprowadziło do zmiany w kierownictwie resortu sprawiedliwości i fiaska przygotowanych projektów.

Mimo upadku tej koncepcji, stan ówczesnych prac nad połączeniem zawodów prawniczych był ważnym impulsem do zmian i miał istotny wpływ na rodzaj argumentacji podnoszonej w trakcie prac sejmowych nad dwoma kolejnymi projektami. Były to:

1. Ustawa z dnia 5 listopada 2009 r. o zmianie ustawy - Kodeks karny, ustawy - Kodeks postępowania karnego, ustawy - Kodeks karny wykonawczy, ustawy - Kodeks karny skarbowy oraz niektórych innych ustaw (weszła w życie 8 czerwca 2010 r.), która zniosła wszelkie ograniczenia podmiotowe występowania radcy prawnego jako pełnomocnika w postępowaniu karnym ${ }^{17}$. Tym samym zrównano $\mathrm{w}$ tym zakresie uprawnienia radcy prawnego z uprawnieniami adwokata. Spotykało się to $\mathrm{w}$ toku prac legislacyjnych $\mathrm{z}$ nieskutecznym sprzeciwem adwokatury, która wskazywała, że wprowadzenie takiej zmiany zburzy jasność rynku świadczenia pomocy prawnej w sprawach karnych oraz podnosiła zarzut możliwości pozostawania przez radców prawnych w stosunku pracy.

2. Ustawa z dnia 18 marca 2010 r. o zmianie ustawy o Trybunale Stanu (weszła w życie 5 czerwca 2010 r.), w świetle której obrońcą w postępowaniu przed Komisją Odpowiedzialności Konstytucyjnej i Trybunałem Stanu mógł był także radca prawny ${ }^{18}$. Poprawkę tę zgłoszono w toku prac legislacyjnych. Wobec opozycji niektórych posłów przewodniczący Komisji zwrócił uwagę, że coraz więcej uregulowań zmierza w kierunku zrównania uprawnień radców prawnych z adwokatami, a w Ministerstwie Sprawiedliwości jest już gotowy projekt ustawy przewidujący połączenie zawodu adwokata i radcy prawnego.

Jednocześnie rozpoczęto prace nad reformą postępowania karnego. Pierwotna wersja projektu zmian ustawy - Kodeks postępowania karnego oraz niektórych innych ustaw, opracowana przez Komisję Kodyfikacyjną Prawa Karnego, nie przewidywała rozszerzenia uprawnień radców prawnych na pełnienie funkcji obrońcy w procesie karnym. Projekt został skierowany do konsultacji społecznych w kwietniu $2011 \mathrm{r}$. i ponownie w styczniu $2012 \mathrm{r}$.

Krajowa Rada Radców Prawnych z pismem z dnia 15 lutego 2012 r. przesłała stanowisko do projektu ustawy oraz uchwałę nr 128/VII/2010 KRRP z dnia 18 czerwca 2010 r. w sprawie projektu ustawy o zmianie ustawy o radcach prawnych, ustawy - Kodeks postępowania karnego oraz niektórych innych ustaw. Stanowisko i uchwała postulowały przyznanie radcom prawnym uprawnienia do

17 Dz.U., nr 206, poz. 1589. Zmiana ta korespondowała z przeprowadzonymi cztery lata wcześniej zmianami ustawy o radcach prawnych.

${ }_{18}$ Art. art. 9d ust. 2 pkt 2 i art. 22a ustawy z dnia 26 marca 1982 r. o Trybunale Stanu (Dz.U. z 2002 r., nr 101, poz. 925 ze zm.), dodany art. 1 pkt 5 i 10 ustawy z dnia 18 marca 2010 r. o zmianie ustawy o Trybunale Stanu (Dz.U., nr 75, poz. 472). 
występowania w charakterze obrońców w sprawach karnych i karnych skarbowych. W odpowiedzi w Ministerstwie Sprawiedliwości został opracowany nowy projekt założeń projektu ustawy o zmianie ustawy - Kodeks postępowania karnego oraz niektórych innych ustaw, którego podstawę stanowił projekt Komisji Kodyfikacyjnej Prawa Karnego.

W dniu 9 maja 2012 r. Rada Ministrów przyjęła projekt założeń, który przewidywał dodatkowe uprawnienia radców prawnych. W uzasadnieniu projektu ustawy wskazano na niezasadność ograniczania uprawnień radców prawnych w zakresie występowania $\mathrm{w}$ charakterze obrońcy w postępowaniu karnym ze względu na brak zasadniczych różnic pomiędzy tymi zawodami. Autorzy projektu nie podzielali obaw związanych z brakiem dostatecznej wiedzy radców prawnych z zakresu prawa i postępowania karnego. Zwrócono uwagę na związek prawa karnego z różnymi dziedzinami prawa, w których od lat specjalizują się radcowie prawni, a rozszerzenie ich uprawnień na sprawy karne pozwoliłoby na kompleksową obsługę ich klientów. Podkreślano, że przyjęcie rozwiązania proponowanego projektem zwiększy dostęp społeczeństwa do usług prawniczych bez zmniejszenia ich jakości, co leży w interesie publicznym ${ }^{19}$.

Mimo że projekt nie został jeszcze przesłany do konsultacji społecznych ${ }^{20}$, w stanowisku z dnia 14 maja 2012 r. Naczelna Rada Adwokacka wyraziła sprzeciw w stosunku do proponowanych rozwiązań przewidujących poszerzenie kręgu podmiotów uprawnionych do występowania w charakterze obrońcy, wskazując na brak gwarancji należytego wykonywania tej funkcji (tj. niezależności i niezawisłości) w odniesieniu do radców prawnych pozostających w stosunku pracy ${ }^{21}$. Niekonsekwencją tej argumentacji było to, że sprzeciw dotyczył wszystkich radców prawnych, bez względu na to, czy pozostają oni w stosunku pracy.

W czerwcu został skierowany do konsultacji społecznych projekt rządowy (z dnia 5 czerwca 2012 r.), który przewidywał zmianę art. 82 ustawy k.p.k. przez nadanie mu brzmienia: „Obrońcą może być jedynie osoba uprawniona do obrony według przepisów o ustroju adwokatury i ustawy o radcach prawnych". Projekt obejmował też zmiany w ustawie o radcach prawnych, dotyczące definicji wykonywania zawodu radcy prawnego (art. 4 u.r.p.) ${ }^{22}$ i pojęcia świadczenia pomocy

${ }^{19}$ Uzasadnienie do projektu ustawy o zmianie ustawy - Kodeks postępowania karnego oraz niektórych innych ustaw (druk sejmowy nr 870), http://orka.sejm.gov.pl/Druki7ka.nsf/0/96832B0 ED113D8FBC1257AB4004F3B04/\%24File/870.pdf [dostęp: 10.05.2016].

${ }^{20}$ J.M. Majewski, Obrońcy art. 82 k.p.k., www.adwokatura.katowice.pl/z-naszej-izby-szczegoly/items/obroncy-art-82-kpk.html [dostęp: 10.05.2016].

${ }^{21}$ Pismo NRA z dnia 14 maja 2012 r. dotyczące projektu ustawy o zmianie ustawy - Kodeks postępowania karnego oraz niektórych innych ustaw, s. 2-3, 8 .

22 Art. 4 u.r.p.: „Wykonywanie zawodu radcy prawnego polega na świadczeniu pomocy prawnej, z wyjątkiem występowania w charakterze obrońcy w postępowaniu karnym i w postępowaniu w sprawach o przestępstwa skarbowe”, otrzymał brzmienie: „Wykonywanie zawodu radcy prawnego polega na świadczeniu pomocy prawnej”. 
prawnej (art. 6 ust. 1 u.r.p. $)^{23}$, oraz dodanie ust. $6 \mathrm{w}$ art. $8 \mathrm{w}$ brzmieniu: „Pomoc prawna świadczona przez radcę prawnego, wykonującego zawód w ramach stosunku pracy, nie może polegać na występowaniu w charakterze obrońcy w postępowaniu karnym". Tak zbudowana norma umożliwiałaby występowanie w roli obrońcy w postępowaniu karnym radcy prawnego, który jest zatrudniony w stosunku pracy, ale nie wykonuje $\mathrm{w}$ tej formie zawodu radcy prawnego.

Naczelna Rada Adwokacka bardzo szybko zajęła stanowisko w piśmie z dnia 18 czerwca 2012 r., w którym po raz kolejny podniosła kwestię braku niezależności radcy prawnego zatrudnionego na etacie. $\mathrm{W}$ odpowiedzi na to stanowisko Minister Sprawiedliwości w krótkim piśmie z dnia 21 czerwca 2012 r. wskazał, że wbrew twierdzeniom zawartym w stanowisku NRA projekt przedstawiony do konsultacji przewiduje wyłączenie z pełnienia funkcji obrońcy radców prawnych pozostających w stosunku pracy.

Krajowa Rada Radców Prawnych w uchwale nr 120/VIII/2012 z dnia 4 lipca 2012 r. pozytywnie zaopiniowała projekt w części dotyczącej rozszerzenia zakresu świadczenia pomocy prawnej przez radców prawnych o występowanie w charakterze obrońcy (nowe brzmienie art. 6 ust. 1 u.r.p. i art. 82 k.p.k.), natomiast negatywnie odniosła się do dodania ust. $6 \mathrm{w}$ art. 8 u.r.p., wprowadzającego wyłączenie radców prawnych wykonujących zawód w ramach stosunku pracy z możliwości występowania w charakterze obrońcy w postępowaniu karnym. Wskazując na niezasadność wprowadzenia takiego ograniczenia, argumentowała, że spowoduje to niespójność systemową prawa, gdyż radca prawny bez względu na formę wykonywania zawodu może występować jako obrońca w sprawach o wykroczenia, wykroczenia skarbowe oraz w postępowaniu przed Komisją Odpowiedzialności Konstytucyjnej i przed Trybunałem Stanu. Ponadto podkreślono, że niejasne jest ratio legis tego przepisu, w szczególności jeśli wyłączenie to miałoby obejmować stosunek pracy z każdym pracodawcą, w tym radcy prawnego zatrudnionego na umowę o pracę przez podmiot określony w art. 8 ust. 1 u.r.p.

Krajowa Rada Radców Prawnych przedstawiła (za pośrednictwem swojego Ośrodka Badań, Studiów i Legislacji) szereg argumentów przemawiających za rozszerzeniem uprawnień radców prawnych, zauważając, że podział na dwa zawody prawnicze, zróżnicowane co do materialnego zakresu świadczonej pomocy prawnej, jest niespotykany w krajach Unii Europejskiej ${ }^{24}$. Wskazano, że radcowie prawni posiadają odpowiednią wiedzę i kompetencje do występowania

${ }^{23}$ Art. 6 ust. 1 u.r.p.: „Zawód radcy prawnego polega na świadczeniu pomocy prawnej, a w szczególności na udzielaniu porad prawnych, sporządzaniu opinii prawnych, opracowywaniu projektów aktów prawnych oraz występowaniu przed sądami i urzędami”, przez nadanie mu brzmienia: „Świadczenie pomocy prawnej przez radcę prawnego polega w szczególności na udzielaniu porad i konsultacji prawnych, sporządzaniu opinii prawnych, opracowywaniu projektów aktów prawnych oraz występowaniu przed urzędami i sądami w charakterze pełnomocnika lub obrońcy".

${ }^{24}$ Opinia Ośrodka Badań, Studiów i Legislacji KRRP z dnia 2 lipca 2012 r., s. 2-3. 
w charakterze obrońcy na zasadach określonych w k.p.k. Przemawia za tym także doświadczenie $\mathrm{w}$ roli pełnomocnika w postępowaniu karnym oraz obrońcy $\mathrm{w}$ różnych postępowaniach, w których $-\mathrm{z}$ uwagi na okoliczność, iż nie mówimy o regulacjach kompleksowych - w sprawach nieuregulowanych odpowiednio stosuje się k.p.k. Zwrócono uwagę, że w obecnym stanie prawnym istnieje kilkadziesiąt ustaw pozakodeksowych przewidujących odpowiedzialność karną, a dziedziny te pozostają w zakresie obsługi prawnej wykonywanej przez radców prawnych, dysponujących bardziej specjalistyczną wiedzą w tym zakresie niż adwokaci, a tym samym dających lepszą gwarancję fachowej obsługi prawnej. Ustawy szczególne, pozakodeksowe często zawierają normy dotyczące czynów zabronionych, będących zarówno przestępstwami, jak i wykroczeniami. W sprawach o niektóre z nich (wykroczenia) radcowie prawni mogli występować jako obrońcy, zaś w sprawach o inne (przestępstwa) nie mogli występować w takim charakterze, choć niejednokrotnie są to zachowania zbliżone, często nieróżniące się nawet samą konstrukcją prawną. Ponadto wskazano, że możliwy jest swobodny przepływ między zawodami radcy prawnego i adwokata. Brak możliwości pełnienia funkcji obrońcy w sprawach karnych przez czynnych radców prawnych jawiła się jako sytuacja sztuczna, tym bardziej że przeniesienie wpisu na listę adwokatów natychmiast (bez dodatkowego szkolenia) powodowało nabycie uprawnień do występowania w roli obrońcy w sprawach karnych.

Argumenty te znalazły uznanie. W dniu 9 października 2012 r. Rada Ministrów przyjęła projekt ustawy o zmianie ustawy - Kodeks postępowania karnego, ustawy - Kodeks karny oraz niektórych innych ustaw, a w dniu 8 listopada 2012 r. skierowała go do Sejmu ${ }^{25}$. Zawierał on przepisy dotyczące rozszerzenia uprawnień radców prawnych do występowania w charakterze obrońcy w postępowaniu karnym. W projekcie tym zmianie uległa treść ust. 6 w art. 8 u.r.p., który otrzymał nowe brzmienie: „Pomoc prawna polegająca na występowaniu przez radcę prawnego $\mathrm{w}$ charakterze obrońcy w postępowaniu karnym może być świadczona w ramach wykonywania przez niego zawodu na podstawie umowy cywilnoprawnej, w kancelarii radcy prawnego oraz w spółce, o której mowa w ust. 1 pod warunkiem, że radca prawny nie pozostaje w stosunku pracy z innymi podmiotami”.

Po pierwszym czytaniu projekt został skierowany do Komisji Nadzwyczajnej do spraw zmian w kodyfikacjach, gdzie w wyżej wspomnianym projektowanym ust. 6 art. 8 u.r.p. dodano (w celu zachowania symetrii uregulowań z ustawą - Prawo o adwokaturze) wyłączenie od wprowadzonego ograniczenia w postaci zd. 2 w brzmieniu: „Zakaz zatrudnienia nie dotyczy pracowników naukowych i naukowo-dydaktycznych" 26 .

${ }^{25}$ Rządowy projekt ustawy o zmianie ustawy - Kodeks postępowania karnego, ustawy Kodeks karny i niektórych innych ustaw (druk sejmowy nr 870), www.sejm.gov.pl/sejm7.nsf/druk. xsp?nr=870 [dostęp: 10.06.2016].

${ }^{26}$ Sprawozdanie komisji (druk sejmowy nr 1586). 
Pracom legislacyjnym towarzyszyła burzliwa debata między przedstawicielami samorządu radcowskiego i adwokackiego. Przedstawiciele KRRP podnosili, że radcowie prawni dysponują także odpowiednią wiedzą teoretyczną, nieodbiegającą od wiedzy adwokatów, gdyż kandydaci na aplikację dostają się na podstawie pozytywnego wyniku identycznego testu, na aplikacji odbywają oni szerokie szkolenie z zakresu prawa karnego materialnego i formalnego, zakończone obowiązkowym kolokwium (naukę uzupełniają obowiązkowe praktyki w wydziałach karnych sądów i prokuraturze), a druga część egzaminu radcowskiego polega na rozwiązaniu zadania z zakresu prawa karnego polegającego na przygotowaniu aktu oskarżenia lub apelacji albo - w przypadku uznania, iż brak jest podstaw do ich wniesienia - na sporządzeniu opinii prawnej w oparciu o opracowane na potrzeby egzaminu akta lub przedstawiony stan faktyczny. Ponadto od wielu lat samorząd radcowski (na szczeblu krajowym przez Centrum Szkolenia Ustawicznego, a na okręgowym - przez rady) organizuje szkolenia z zakresu prawa karnego materialnego i procesowego.

$\mathrm{W}$ trakcie długiego procesu legislacyjnego na tym niewielkim wycinku regulacji prawnej - patrząc z perspektywy wielkiej reformy modelu postępowania karnego - prowadzono zażartą dyskusję. W celu uspokojenia przedstawicieli samorządów prawniczych przewodniczący Komisji zorganizował nawet spotkanie pojednawcze, które skończyło się fiaskiem, gdyż każda ze stron pozostała przy swoich poglądach, odpowiednio je uzasadniając.

W czasie dalszych prac zgłaszano nowe poprawki, np. wprowadzenia wzoru oświadczeń składanych przez radców prawnych-obrońców o tym, że nie pozostają w stosunku pracy, na wzór oświadczeń, jakie radca prawny reprezentujący osoby fizyczne składał w pełnomocnictwie w postępowaniu cywilnym w latach 1997-200727. Pojawiały się również poprawki absurdalne, „heroiczne” w wykonaniu jednego z posłów-adwokatów, właściwie niezwiązane z projektem, a dotyczące ustawowego przeniesienia radców prawnych niepozostających w stosunku pracy do adwokatury. Obie poprawki nie zostały uwzględnione.

Po drugim czytaniu na posiedzeniu Sejmu, w trakcie prac Komisji Nadzwyczajnej, w dniu 28 sierpnia 2013 r. były głosowane nowe poprawki dotyczące skreślenia przepisów przewidujących zmiany w k.p.k. i u.r.p., nadających radcom prawnym uprawnienia do występowania $\mathrm{w}$ charakterze obrońcy w postępowaniu karnym $^{28}$. Poprawki te zostały odrzucone i taka rekomendacja Komisji Nadzwyczajnej została podtrzymana w trakcie trzeciego czytania na posiedzeniu Sejmu w dniu 30 sierpnia $2013 \mathrm{r}$.

${ }^{27}$ Art. 89 § 3 k.p.c. dodany przez art. 4 pkt 1 ustawy z dnia 22 maja 1997 r. o zmianie ustawy - Prawo o adwokaturze, ustawy o radcach prawnych i niektórych innych ustaw (Dz.U. z 1997 r., nr 75, poz. 471); art. 1 pkt 4 ustawy z dnia 9 maja 2007 r. zmieniającej k.p.c. i inne niektóre ustawy (Dz.U., nr 121, poz. 831).

${ }^{28}$ Sprawozdanie komisji (druk sejmowy nr 1586-A). 
W Senacie poddano głębszej analizie brzmienie art. 8 ust. 6 u.r.p. Efektem prac komisji senackich i protestów adwokatury wskazujących na asymetrię przyjętych rozwiązań prawnych dla dwóch zawodów prawniczych była uchwała Senatu z dnia 20 września 2013 r., w której zaproponowano zmianę ust. 6 art. 8 u.r.p. przez skreślenie wyrazów „,z innymi podmiotami”. Uznano, że przyznanie uprawnienia do występowania w charakterze obrońcy tym radcom, którzy są zatrudnieni w kancelarii radcy prawnego lub spółce prawniczej, jest zbyt daleko idące, biorąc pod uwagę, że adwokat nie może pozostawać w stosunku pra$\mathrm{cy}^{29}$. Niepowodzeniem skończyła się propozycja wprowadzenia stosunku pracy w kancelariach i spółkach prawniczych jako dopuszczalnej formy wykonywania zawodu adwokata. W ocenie adwokatury rozwiązanie dotyczące stosunku pracy było niedopuszczalne, mimo że jest ono znane w kilku krajach Unii Europejskiej. Występuje ono także w adwokaturze francuskiej, do tradycji której nawiązuje nasza palestra. Po analizie i poparciu tej poprawki senackiej na posiedzeniu Komisji Nadzwyczajnej została ona przyjęta przez Sejm trzy dni później, na posiedzeniu 27 września 2013 r. $^{30}$

Należy zwrócić uwagę, że wraz ze zmianą k.p.k. (w tym art. 82) dokonano powiązanej zmiany u.r.p., co jest chlubnym wyjątkiem w dotychczasowej praktyce legislacyjnej. Kontrowersyjny art. 8 ust. 6 u.r.p. ostatecznie otrzymał brzmienie: „Pomoc prawna polegająca na występowaniu przez radcę prawnego w charakterze obrońcy w sprawach o przestępstwa i przestępstwa skarbowe może być świadczona w ramach wykonywania przez niego zawodu na podstawie umowy cywilnoprawnej, w kancelarii radcy prawnego oraz w spółce, o której mowa w ust. 1 tego artykułu, pod warunkiem, że radca prawny nie pozostaje w stosunku pracy. Zakaz zatrudnienia nie dotyczy pracowników naukowych i naukowo-dydaktycznych".

Reforma procesu karnego zmieniająca jego model weszła w życie 1 lipca 2015 r., wpływając pośrednio na dotychczasowy rynek usług prawniczych ${ }^{31}$.

Jeszcze przed wejściem w życie nowych przepisów Naczelna Rada Adwokacka złożyła do Trybunału Konstytucyjnego wniosek o zbadanie zgodności:

- art. 6 ust. 1 i art. 8 ust. 6 u.r.p. z art. 17 ust. 1 Konstytucji w zakresie, w jakim ograniczają wpływ samorządu adwokackiego na sprawowanie pieczy nad należytym występowaniem $\mathrm{w}$ charakterze obrońcy w sprawach o przestępstwa i przestępstwa skarbowe,

- art. 8 ust. 6 ustawy o radcach prawnych z art. 32 ust. 1 Konstytucji (statuującym zasadę równości obywateli wobec prawa) przez to, że pozwala radcom

${ }^{29}$ Pkt 17 uchwały Senatu RP z dnia 20 września 2013 r. w sprawie ustawy o zmianie ustawy - Kodeks postępowania karnego oraz niektórych innych ustaw (druk sejmowy nr 1734).

${ }^{30}$ Sprawozdanie komisji (druk sejmowy nr 1745).

${ }^{31}$ Ustawa z dnia 27 września 2013 r. o zmianie ustawy - Kodeks postępowania karnego oraz niektórych innych ustaw (Dz.U., nr 13, poz. 1247). Prezydent RP podpisał ustawę 17 października $2013 \mathrm{r}$. 
prawnym na łączenie stosunku pracy z innymi formami wykonywania przez nich zawodu prawniczego w sprawach innych niż występowanie w charakterze obrońcy w sprawach o przestępstwa i przestępstwa skarbowe,

- art. 6 ust. 1 i art. 8 ust. 6 ustawy o radcach prawnych oraz art. 82 k.p.k. $\mathrm{z}$ art. 42 Konstytucji przez to, że dopuszczają występowanie przez radcę prawnego w charakterze obrońcy w sprawach o przestępstwa i przestępstwa skarbowe ${ }^{32}$.

We wniosku podniesiono między innymi, że wprowadzone nowelizacją z dnia 27 września 2013 r. przepisy:

- pogarszają atrakcyjność zawodu adwokata w porównaniu z zawodem radcy prawnego ze względu na to, że radca prawny może łączyć pozostawanie w stosunku pracy ze świadczeniem pomocy prawnej we wszystkich innych sprawach oprócz występowania w charakterze obrońcy w sprawach o przestępstwa i przestępstwa skarbowe,

- pogarszają sytuację zawodową adwokatów specjalizujących się w sprawach o przestępstwa i przestępstwa skarbowe wskutek zwiększenia liczby osób uprawnionych do pełnienia roli obrońcy, a ponadto pogarszają sytuację zawodową adwokatów specjalizujących się w innych sprawach wskutek wzrostu liczby prawników uprawnionych do świadczenia pomocy prawnej w tych sprawach w związku z możliwością ich prowadzenia przez prawników zatrudnionych na umowę o pracę,

- eliminują dotychczasową wyłączność adwokatów do występowania w charakterze obrońcy w sprawach o przestępstwa i przestępstwa skarbowe.

Wskazano także na zacieranie się granic między zawodem adwokata i radcy prawnego oraz na dyskryminujący charakter przekazania radcom prawnym wyłącznie uprawnień adwokatów, nie obciążając ich obowiązkami adwokatów związanych z wykonywaniem wolnego zawodu.

Do wniesionego wniosku NRA o zbadanie konstytucyjności wyżej wymienionych przepisów w ramach działalności Ośrodka Badań, Studiów i Legislacji KRRP został przygotowany komentarz pozwalający na jego analizę pod względem prawnym, chociaż zakładano przede wszystkim brak legitymacji czynnej Naczelnej Rady Adwokackiej do wystąpienia z takim wnioskiem do Trybunału Konstytucyjnego ${ }^{33}$. Niemniej można się pokusić o ocenę merytoryczną tych zarzutów, co - z powodów, o których niżej - w dużym stopniu nie stało się udziałem Trybunału Konstytucyjnego. $Z$ uwagi na to, że jedynie dwa zarzuty (pkt 1 i 3) dotyczyły zmian wprowadzonych przez nowelizację k.p.k. i powiązanych z nią zmian u.r.p. nadających uprawnienia do występowania w charakterze obrońcy w postępowaniu karnym, omówienie zostanie tylko do nich ograniczone.

${ }^{32}$ Wniosek NRA z dnia 22 kwietnia 2015 r. o zbadanie zgodności ustaw z Konstytucją RP, www. adwokatura.pl/admin/wgrane_pliki/file-trybunalnraradcyobrony-11446.pdf [dostęp: 14.05.2016].

${ }^{33}$ Opinię w tym zakresie sporządził współpracownik Kierownika OBSiL KRRP dr hab. Sławomir Patyra, prof. nadzw. 
Niezgodność kwestionowanych przepisów z art. 17 ust. 1 Konstytucji wnioskodawca dostrzegał w tym, że zezwala się na występowanie w roli adwokata radcy prawnemu, który nie jest członkiem samorządu adwokackiego, co ma w jego opinii naruszać wymagania dotyczące zawodu zaufania publicznego, do którego wykonywania jest wymagana przynależność do samorządu. Trudno jednak znaleźć jakikolwiek łącznik między zakwestionowanymi przepisami ustawy o radcach prawnych, które mają charakter kompetencyjny i odnoszą się do prawnych form wykonywania zawodu zaufania publicznego, a wzorcem kontroli w postaci art. 17 ust. 1 Konstytucji, który przewiduje, że w drodze ustawy można tworzyć samorządy zawodowe reprezentujące osoby wykonujące zawody zaufania publicznego i sprawujące pieczę nad należytym wykonywaniem tych zawodów w granicach interesu publicznego i dla jego ochrony. Należałoby więc zarzut ten uznać za oparty na niewłaściwym wzorcu kontroli. Wzorzec kontroli wskazany przez wnioskodawcę w kolejnym zarzucie to art. 42 ust. 2 Konstytucji, który stanowi, że każdy, przeciwko komu jest prowadzone postępowanie karne, ma prawo do obrony we wszystkich stadiach postępowania. Może on w szczególności wybrać obrońcę lub na zasadach określonych w ustawie korzystać z obrońcy $\mathrm{z}$ urzędu. Niezgodne z nim miałyby być znowelizowane przepisy ustawy o radcach prawnych - art. 6 ust. 1 i art. 8 ust. 6 oraz dodatkowo art. 82 k.p.k. Wnioskodawca podnosił, że ,ustawa w istocie zmienia Konstytucję, ponieważ zmienia zastane pojęcie obrońcy, stanowiąc, że może być nim również radca prawny". Zarzut ten był całkowicie niezasadny, bowiem wskazana regulacja nie dość, że nie godziła w prawo do obrony, to jeszcze wzmacniała gwarancje jego realizacji, ponieważ zwiększała dostęp do profesjonalnych usług prawnych w zakresie obrony w postępowaniu karnym.

Wymiana poglądów, w ramach polemiki między przedstawicielami samorządów prawniczych dotyczącej poszerzenia uprawnień radców prawnych, była prowadzona nie tylko $\mathrm{w}$ toku procesu legislacyjnego, ale również po skierowaniu wzmiankowanego wniosku do Trybunału Konstytucyjnego na łamach prasy krajowej. Wypowiedzi prasowe osób związanych z Ośrodkiem Badań, Studiów i Legislacji KRRP były często odpowiedzią na zbyt ostre w swoim tonie publiczne wypowiedzi pełnomocników Naczelnej Rady Adwokackiej w postępowaniu przed Trybunałem Konstytucyjnym ${ }^{34}$. Nasiliły się one po wydaniu postanowienia Trybunału Konstytucyjnego z dnia 24 września 2015 r., w którym odmówił on nadania wnioskowi NRA dalszego biegu. W ramach wstępnej kontroli skargi Trybunał Konstytucyjny stwierdził brak czynnej legitymacji Naczelnej Rady Adwokackiej do wystąpienia w tej sprawie do Trybunału Konstytucyjnego, uzasadniając swoje rozstrzygnięcie brakiem bezpośredniego związku kwestionowanych przez adwokaturę przepisów z wykonywaniem zawodu adwokata. Na postano-

${ }^{34}$ Zob. np. S. Patyra, Czy adwokat jest synonimem obrońcy, „Gazeta Prawna” 2015, http:// prawo.gazetaprawna.pl/artykuly/911095,adwokat-synonimem-obroncy.html [dostęp: 10.06.2016]. 
wienie Trybunału Konstytucyjnego Naczelna Rada Adwokacka złożyła zażalenie z dnia 6 października 2015 r., w którym wniosła o uchylenie zaskarżonego postanowienia $\mathrm{w}$ całości i skierowanie sprawy do rozpoznania na rozprawie w pełnym zakresie objętym wnioskiem. Trybunał Konstytucyjny w dniu 23 grudnia 2015 r. postanowił nie uwzględnić zażalenia $\mathrm{NRA}^{35}$. W uzasadnieniu postanowienia wskazano, że rozszerzenie podmiotów uprawnionych do występowania w charakterze obrońcy $\mathrm{w}$ sprawach o przestępstwa i przestępstwa skarbowe stanowi wyłączną kompetencję ustawodawcy. To ustawodawca, tworząc poszczególne samorządy zawodowe, jest uprawniony do określenia zakresu pieczy nad wykonywaniem poszczególnych zawodów, w tym również do przyznania nowych uprawnień określonej grupie zawodowej. W ocenie Trybunału Konstytucyjnego przyznanie radcom prawnym kompetencji do występowania w charakterze obrońcy w sprawach o przestępstwa i przestępstwa skarbowe pośrednio wpływa na sytuację adwokatów, aczkolwiek nie oznacza to, że Naczelna Rada Adwokacka posiada legitymację do kwestionowania konstytucyjności przepisów, które kształtują sytuację prawną innego samorządu zawodowego. Regulacje te nie dotyczą bowiem bezpośrednio zakresu sprawowania pieczy nad wykonywaniem zawodu adwokata. Trybunał podkreślił, że przedstawiciele określonego zawodu mogą domagać się kontroli wyłącznie tych aktów normatywnych, które są bezpośrednio związane $\mathrm{z}$ wykonywaniem danej profesji. Przyznanie określonych uprawnień - nawet takich, które dotychczas były zastrzeżone do wyłącznej kompetencji przedstawicieli innego zawodu - innej grupie zawodowej wynika natomiast z prawa ustawodawcy do swobodnego określania zakresu działania poszczególnych samorządów. Trybunał Konstytucyjny przesądził tym samym, że Adwokatura Polska nie ma legitymacji do występowania z wnioskiem o zbadanie konstytucyjności przepisów dotyczących zakresu działania przedstawicieli innych zawodów prawniczych. Rozstrzygnięcie to ostatecznie zakończyło postępowanie przed Trybunałem Konstytucyjnym zainicjowane przez Naczelną Radę Adwokacką i spór, jaki istniał z tego powodu między samorządami prawniczymi.

$\mathrm{Z}$ uprawnieniem do występowania $\mathrm{w}$ charakterze obrońcy $\mathrm{w}$ postępowaniu karnym wiąże się obowiązek (a zarazem uprawnienie) występowania jako obrońca z urzędu, który jest wyznaczany przez prezesa sądu, sąd lub referendarza sądowego z listy obrońców (art. $78 \S 1$, art. 80a $\S 1$ i art. 81a $\S 1$ ustawy nowelizującej k.p.k. z dnia 27 września 2013 r.). Sposób zapewnienia oskarżonemu korzystania $\mathrm{z}$ pomocy obrońcy $\mathrm{z}$ urzędu, w tym sposób ustalania listy obrońców udzielających pomocy prawnej z urzędu, sposób wyznaczania obrońcy udzielającego

${ }^{35}$ Postanowienie TK z dnia 23 grudnia 2015 r., sygn. akt Tw 8/15. 
pomocy prawnej z urzędu oraz sposób kontaktu z obrońcą w sprawach pilnych, mając na uwadze konieczność zapewnienia prawidłowego toku postępowania oraz prawidłowej realizacji prawa do obrony, miał być określony w drodze rozporządzenia Ministra Sprawiedliwości. Delegacja została pierwotnie zawarta w art. 81a $\S 2$ ustawy nowelizującej k.p.k. z dnia 27 września 2013 r. Przepis ten jednak nie wszedł w życie w tym brzmieniu, gdyż rozpoczęto kolejne prace nad zmianą nowelizacji k.p.k. przed jej wejściem w życie. W trakcie prac nad projektem ustawy o zmianie ustawy - Kodeks karny oraz niektórych innych ustaw w Komisji zaproponowano zmianę ustawy nowelizującej z dnia 27 września 2013 r. w zakresie art. 81a i art. 88 k.p.k. ${ }^{36}$

Zmiana dotycząca art. 81a k.p.k. nie budziła poważniejszych wątpliwości ze strony samorządu radcowskiego, lecz niejasny był cel rozszerzenia lub uszczegółowienia zakresu delegacji do wydania rozporządzenia Ministra Sprawiedliwości zawartej w nowym $\S 4$ tego artykułu. Dotyczyło to zwłaszcza sformułowania w art. 81a $\S 4$ pkt 2 odnoszącego się do ,trybu i sposobu przekazywania do sądu wniosku o wyznaczenie obrońcy z urzędu oraz szczegółowy tryb rozpoznawania takiego wniosku, mimo że art. 81a $\S 4$ pkt 1 mówił o sposobie wyznaczania obrońcy udzielającego pomocy prawnej z urzędu". Nie zostało to wyjaśnione ani w uzasadnieniu projektu, ani w trakcie prac legislacyjnych, a projekt aktu wykonawczego nie został dołączony do projektu ustawy. Być może obawiano się zarzutu przekroczenia delegacji w przypadku umieszczenia takiego trybu w akcie wykonawczym, który mógł służyć preselekcji przy wyznaczaniu obrońców $\mathrm{z}$ urzędu z udziałem wnioskującego.

Zastrzeżenia Krajowej Rady Radców Prawnych budziło natomiast nowe brzmienie art. 88 k.p.k.: „Pełnomocnikiem może być adwokat lub radca prawny. Do pełnomocnika stosuje się odpowiednio art. 77, art. 78, art. 81a § 1-3, art. 83, art. 84 , art. $86 \S 2$ oraz przepisy wydane na podstawie art. 81a $\S 4$ ". KRRP w stanowisku z dnia 16 grudnia 2014 r. zwróciła się do Komisji Nadzwyczajnej do spraw zmian w kodyfikacjach o wprowadzenie poprawki do sprawozdania podkomisji przez odstąpienie od zmiany art. 88 k.p.k. Zmiana tego przepisu powoduje, że do wyznaczania pełnomocników występujących z urzędu będzie brana pod uwagę lista obrońców, na której nie będzie radców prawnych pozostających w stosunku pracy, co uniemożliwia powierzenie tym radcom pełnienia roli pełnomocnika wyznaczanego z urzędu w postępowaniu karnym. KRRP opowiedziała się przeciwko takiemu rozwiązaniu, wskazując, że jest to krok wstecz w stosunku do celu regulacji przyjętych ustawą nowelizującą z dnia 27 września 2013 r. i odbiera radcom prawnym pozostającym w stosunku pracy nabyte uprawnienia, $\mathrm{z}$ których do tej pory mogli korzystać. Wskazano, że wprowadzenie takiego ograniczenia narusza

${ }^{36}$ Rządowy projekt ustawy o zmianie ustawy - Kodeks karny oraz niektórych innych ustaw z dnia 15 maja 2014 r. (druk sejmowy nr 2393); sprawozdanie komisji (druk sejmowy nr 2981) $\mathrm{z}$ dnia 3 grudnia $2014 \mathrm{r}$. 
zasadę proporcjonalności, o której mowa w art. 31 ust. 3 Konstytucji, ponieważ uniemożliwienie znacznej grupie radców prawnych występowania jako pełnomocnik z urzędu w procesie karnym nie jest uzasadnione ani z punktu widzenia bezpieczeństwa państwa lub porządku publicznego, ani innych wartości konstytucyjnych wskazanych w powołanym wyżej przepisie Konstytucji. Uwagi tej w trakcie wspólnych posiedzeń komisji senackich nie uwzględniono (także z uwagi na konieczność pilnego uchwalenia nowelizacji) i w ustawie z dnia 20 lutego 2015 r., nowelizującej między innymi przepisy zmieniające kodeks postępowania karnego, utrzymano kwestionowane brzmienie art. 88 k.p.k. ${ }^{37}$

Zakończenie prac nad ustawą dało impuls do szybkiego przygotowania aktów wykonawczych, a wśród nich rozporządzenia w sprawie zapewnienia oskarżonemu korzystania z pomocy obrońcy z urzędu. Nad wstępnymi rozwiązaniami pracowała już wcześniej specjalna komisja do spraw monitowania zmian w kodeksie postępowania karnego w Ministerstwie Sprawiedliwości. Projekt rozporządzenia został pod koniec stycznia 2015 r. przesłany do KRRP, która w opinii z dnia 9 lutego 2015 r. krytycznie odniosła się do § 6 ust. 1 i 2, § 9 ust. 1-3 oraz $\S 8$ projektu rozporządzenia ${ }^{38}$. Przepisy te były związane $\mathrm{z}$ tworzeniem list obrońców z urzędu i szczegółowym trybem rozpoznawania wniosku o wyznaczenie obrońcy z urzędu. $\S 6$ projektu przewidywał podział listy obrońców na dwie części: „Adwokaci” i „Radcy prawni”, a § 9 przewidywał przemienne wyznaczanie obrońców z obu list. W opinii podkreślano niezasadność rozróżniania, w sytuacji identycznych kompetencji obrończych, radców prawnych i adwokatów przez tworzenie odrębnych list, ponieważ niepotrzebnie utrwala ono podział obrońców, który na poziomie ustawowym został usunięty. Z kolei $\S 8$ projektu rozporządzenia przewidywał dla oskarżonego uprawnienie do wskazania, czy żąda wyznaczenia jako obrońcy z urzędu adwokata czy radcy prawnego, jednak żądanie to nie miało być dla sądu wiążące. W stanowisku wskazano, że zawarta w art. 81a k.p.k. delegacja do wydania rozporządzenia nie przewiduje jakiegokolwiek wpływu osoby korzystającej z pomocy prawnej z urzędu na to, czy jako obrońca zostanie mu wyznaczony radca prawny czy adwokat. Z tego względu wadliwie zostało zrealizowane uprawnienie $\mathrm{z}$ art. 81a $\S 4$ k.p.k. w zakresie, $w$ jakim $\mathrm{w} \S 8$ projektu rozporządzenia przyznano oskarżonemu uprawnienie do żądania w składanym wniosku o wyznaczenie obrońcy z urzędu wyznaczenia mu w tym charakterze adwokata albo radcy prawnego. Wskazano na niezgodność $\S 8$ rozporządzenia z art. 92 Konstytucji, ponieważ jego wydanie nastąpiło z prze-

${ }^{37}$ Ustawa o zmianie ustawy - Kodeks karny oraz niektórych innych ustaw (Dz.U. z 2015 r., poz. 396). Prezydent RP podpisał ustawę 12 marca $2015 \mathrm{r}$.

38 Projekt rozporządzenia Ministra Sprawiedliwości w sprawie sposobu zapewnienia oskarżonemu korzystania z pomocy obrońcy z urzędu z dnia 28 stycznia 2015 r. (nr z wykazu A95); stanowisko KRRP z dnia 9 lutego 2015 r. dotyczące projektu rozporządzenia MS w sprawie sposobu zapewnienia oskarżonemu korzystania z pomocy obrońcy z urzędu, www.bibliotekakirp. pl/items/show/390 [dostęp: 15.05.2016]. 
kroczeniem upoważnienia ustawowego. Sygnalizowano także, że brak związania sądu żądaniem oskarżonego sprawia, że uprawnienie do wskazania obrońcy jest iluzoryczne, niemniej stwarza to ryzyko - w przypadku niewyznaczenia obrońcy zgodnie z żądaniem - kwestionowania postanowień sądu, co może wydłużyć postępowanie. Postulowano więc zmianę $\S 6$ ust. 1 i 2 i $\S 9$ ust. 1-3 oraz skreślenie $\S 8$ projektu rozporządzenia. W ostatecznym brzmieniu rozporządzenia w sprawie zapewnienia oskarżonemu korzystania z pomocy obrońcy z urzędu została uwzględniona jedna uwaga KRRP przez przyjęcie rozwiązania prowadzenia jednej listy obrońców w porządku alfabetycznym, składającej się z radców prawnych i adwokatów. Nie uwzględniono natomiast drugiego postulatu.

Zgodnie z treścią rozporządzenia Ministra Sprawiedliwości z dnia 27 maja 2015 r. w sprawie sposobu zapewnienia oskarżonemu korzystania z pomocy obrońcy z urzędu ${ }^{39}$ rady okręgowych izb radców prawnych przygotowały wykazy radców prawnych deklarujących gotowość do udzielania oskarżonym pomocy prawnej z urzędu oraz radców prawnych uprawnionych do obrony w postępowaniu karnym (§ 3). Było to możliwe na skutek szybkich zmian w przepisach wewnętrznych samorządu radców prawnych, zobowiązujących radców prawnych do przedłożenia informacji o pozostawaniu w stosunku pracy oraz oświadczeń o gotowości do występowania w charakterze obrońcy z urzędu w postępowaniu karnym. Pierwsze wykazy ze wskazanymi w rozporządzeniu informacjami ( 4 ust. 2) miały być przekazane przez rady okręgowych izb radców prawnych prezesom właściwych sądów do dnia 31 lipca 2015 r. według stanu na dzień 1 lipca 2015 r. (§ 15 ust. 1). Nie odnotowano opóźnień w wykonaniu tego obowiązku ze strony samorządu radcowskiego. Potknięcia w sporządzanych po raz pierwszy wykazach radców prawnych zostały, po sygnalizacji ze strony prezesów sądów, skorygowane.

Zgodnie $\mathrm{z}$ informacjami z okręgowych izb radców prawnych łącznie gotowość do występowania w charakterze obrońcy w sprawach karnych w 2015 r. zadeklarowało 1565 radców prawnych, zaś uprawnionych radców prawnych do występowania w charakterze obrońcy było łącznie 10 842. Oznacza to, że na listach A było łącznie 1565 radców prawnych, zaś na listach B - 9277. Podział ten w poszczególnych okręgowych izbach radców prawnych prezentuje tab. 1.

Tab. 1. Gotowość radców prawnych do występowania w charakterze obrońcy w sprawach karnych w 2015 r.

\begin{tabular}{|l|c|c|}
\hline OIRP & Liczba uprawnionych & Liczba zdeklarowanych \\
\hline Białystok & 362 & 73 \\
\hline Bydgoszcz & 254 & 53 \\
\hline
\end{tabular}

${ }^{39}$ Rozporządzenie Ministra Sprawiedliwości z dnia 27 maja 2015 r. w sprawie sposobu zapewnienia oskarżonemu korzystania z pomocy obrońcy z urzędu (Dz.U. z 2015 r., nr 816). 
Pobrane z czasopisma Studia Iuridica Lublinensia http://studiaiuridica.umcs.pl Data: 26/04/2023 14:19:51

Ewolucja statusu radcy prawnego w postępowaniu karnym

\begin{tabular}{|l|r|r|}
\hline Gdańsk & 562 & 63 \\
\hline Katowice & 1016 & 173 \\
\hline Kielce & 357 & 38 \\
\hline Koszalin & 125 & 52 \\
\hline Kraków & 692 & 118 \\
\hline Lublin & 524 & 87 \\
\hline Łódź & 223 & 45 \\
\hline Olsztyn & 64 & 37 \\
\hline Opole & 455 & 69 \\
\hline Poznań & 899 & 139 \\
\hline Rzeszów & 250 & 79 \\
\hline Szczecin & 362 & 60 \\
\hline Toruń & 255 & 73 \\
\hline Wałbrzych & 396 & 190 \\
\hline Warszawa & 3120 & 99 \\
\hline Wrocław & 543 & 28 \\
\hline Zielona Góra & 383 & 1565 \\
\hline RAZEM & 10842 & \\
\hline
\end{tabular}

Źródło: opracowanie własne.

Nieco inaczej wyglądało zachowanie samorządu adwokackiego, chociaż obstrukcja wykonania tego obowiązku była incydentalna i miała cechy protestu przeciwko niskim stawkom obrońców i pełnomocników występujących z urzędu oraz kształtowi ustawy o nieodpłatnej pomocy prawnej ${ }^{40}$. W dniu 28 lipca $2015 \mathrm{r}$. Okręgowa Rada Adwokacka w Opolu podjęła uchwałę nr 40/07/2015 w sprawie wstrzymania się z przekazaniem do właściwych prezesów sądów wykazu obrońców z urzędu zgodnie z rozporządzeniem Ministra Sprawiedliwości z dnia 27 maja 2015 r. w sprawie sposobu zapewnienia oskarżonemu korzystania z pomocy obrońcy z urzędu. Zbliżona, aczkolwiek nie tak rygorystyczna, była także podjęta tydzień wcześniej uchwała z dnia 21 lipca 2015 r. Prezydium NRA nr 84/2015 w części wskazującej jako formę protestu nieprzedstawianie przez okręgowe rady adwokackie wykazu wskazanego w $\S 2$ pkt 2 rozporządzenia, obejmującego adwokatów uprawnionych do obrony w postępowaniu karnym. Minister Sprawiedliwości zaskarżył te uchwały do Sądu Najwyższego, zarzucając im niezgodność z art. 1 ust. 1, art. 3 ust. 1 pkt 1 oraz art. 212 ust. 3 ustawy - Prawo o adwokaturze, $\S 2$ pkt 2 wskazanego wyżej rozporządzenia w zw. z art. 81a § 1 k.p.k. oraz art. 17

${ }^{40}$ Ustawa $\mathrm{z}$ dnia 5 sierpnia 2015 r. o nieodpłatnej pomocy prawnej oraz edukacji prawnej (Dz.U. z 2015 r., poz. 1255). 
ust. 1 i art. 45 ust. 1 Konstytucji. Minister Sprawiedliwości podniósł, że zaskarżone uchwały pozostają w sprzeczności z celami adwokatury, której zadaniem jest sprawowanie pieczy nad prawidłowym wykonywaniem zawodu adwokata w granicach interesu publicznego i dla jego ochrony. Sąd Najwyższy w dniu 5 listopada $2015 \mathrm{r}$. uchylił wyżej wymienione uchwały jako sprzeczne z prawem ${ }^{41}$.

Z chwilą wejścia nowelizacji k.p.k. w życie rozpoczęto trudne rozmowy samorządów prawniczych z Ministerstwem Sprawiedliwości w sprawie zmiany rozporządzeń taryfowych ${ }^{42}$. Pod koniec lipca od rozmów odstąpiła adwokatura z uwagi na brak postępu w sprawie stawek dla obrońców i pełnomocników z urzę$\mathrm{du}$, a ciężar dalszych negocjacji spoczął na przedstawicielach Krajowej Rady Radców Prawnych ${ }^{43}$. Jednocześnie pojawiły się uwagi KRRP do rozporządzenia Ministra Sprawiedliwości z dnia 27 maja 2015 r. w sprawie sposobu zapewnienia oskarżonemu korzystania z pomocy obrońcy z urzędu. W pismach z dnia 30 lipca i 5 sierpnia 2015 r. została zasygnalizowana potrzeba zmiany rozporządzenia przez usunięcie z wykazów radców prawnych informacji dotyczącej adresu zamieszkania radcy prawnego ze względu na ochronę prawa do prywatności. Tym samym kontakt oskarżonego z radcą prawnym miał być oparty na adresie do doręczeń. Druga zmiana dotyczyła wprowadzenia zmiany mechanizmu ustalania listy obrońców w sytuacji, gdy liczba radców prawnych i adwokatów deklarujących gotowość do pełnienia funkcji obrońcy z urzędu (lista A) w ocenie prezesa

${ }^{41}$ Wyrok SN z dnia 5 listopada 2015 r., sygn. akt III ZS 9/15. W sentencji wyroku Sąd Najwyższy zaznaczył, iż poprzestał na uchyleniu zaskarżonej uchwały bez przekazania sprawy do ponownego rozpoznania, gdyż rodzaj sprzeczności z prawem postanowień uchwał ORA czyni bezprzedmiotowym ponowne rozpoznawanie tej samej kwestii, natomiast obowiązek przedstawienia wykazów obrońców z urzędu, określonych w $§ 2$ pkt 1 i 2 rozporządzenia, powinien być zrealizowany niezwłocznie. Jak bowiem podkreślono w uzasadnieniu wyroku, z brzmienia przepisu art. 21 ust. 3 zd. 1 Prawa o adwokaturze, w powiązaniu z art. 28, jasno wynika obowiązek adwokata (a nie „,dobrowolność”) do świadczenia pomocy prawnej z urzędu na określonym obszarze, którego zakres należy ustalać na podstawie $\S 2$ rozporządzenia wykonawczego w zw. z $\S 9$ ust. 1 zd. 2 rozporządzenia, co w ocenie Sądu Najwyższego stanowi respektowanie zasady wynikającej z art. 21 ust. 3 Prawa o adwokaturze. Zob. też: SN uchylit uchwaty dotyczace formy protestu Adwokatury, www.adwokatura.pl/z-zycia-nra/sn-uchylil-uchwaly-dotyczace-formy-protestu-adwokatury [dostęp: 14.06.2016]. Uchylona została także uchwała z dnia 14 czerwca 2015 r. nr 4 Zgromadzenia Warszawskiej Izby Adwokackiej w części pkt 4 ppkt 2, tj. w części zobowiązującej Okręgową Radę Adwokacką w Warszawie do niewyznaczania adwokatów do pełnienia obowiązków wynikających ze zleconych przez sądy czynności jako pełnomocników z urzędu w sprawach cywilnych, administracyjnych i sądowo-administracyjnych przez okres 1 miesiąca.

4229 lipca 2015 r. Minister Sprawiedliwości Borys Budka podpisał rozporządzenia zmieniające rozporządzenia w sprawie opłat za czynności radców prawnych i adwokatów oraz ponoszenia przez Skarb Państwa kosztów nieopłaconej pomocy prawnej udzielonej z urzędu (Dz.U. z 2015 r., poz. 1078; Dz.U. z 2015 r., poz. 1079).

${ }^{43}$ Stanowisko KRRP do projektu rozporzadzenia Ministra Sprawiedliwości w sprawie opłat za czynności radców prawnych, http://kirp.pl/stanowisko-krrp-do-projektu-rozporzadzeniaministra-sprawiedliwosci-w-sprawie-oplat-za-czynnosci-radcow-prawnych [dostęp: 14.06.2016]. 
właściwego sądu jest niewystarczająca. Zaproponowano zmianę $\S 6$ ust. 2 rozporządzenia w ten sposób, aby w przypadku, gdy przedstawione wykazy radców prawnych i adwokatów ( $\$ 2$ pkt 1 i $\S 3$ pkt 1 ) zawierałyby niewystarczającą liczbę radców prawnych i adwokatów, prezes właściwego sądu zwracał się do okręgowej rady adwokackiej oraz rady okręgowej izby radców prawnych o wskazanie w terminie nie krótszym niż 7 dni dodatkowych radców prawnych, o których mowa w $\S 2$ pkt 1 i $\S 3$ pkt 1, określając ich liczbę. Dopiero po bezskutecznym upływie wyżej wymienionego terminu prezes sądu przystępowałby do ułożenia listy obrońców składającej się ze wszystkich adwokatów i radców prawnych umieszczonych w wykazach, o których mowa w $\S 2$ i 3 rozporządzenia ${ }^{44}$. Dzięki temu rozwiązaniu ciężar zapewnienia odpowiedniej liczby obrońców z urzędu będzie spoczywał na organach samorządu, które są lepiej zorientowane w kwestii wiedzy i obszarów praktyki członków samorządu i mają możliwość przeprowadzenia z nimi wcześniejszych konsultacji co do możliwości podjęcia się pełnienia funkcji obrońcy. Na zasadność takiego rozwiązania wskazywała również $\mathrm{NRA}^{45}$. Uwagi te zostały uwzględnione w zmianie z dnia 22 października 2015 r. rozporządzenia Ministra Sprawiedliwości z dnia 27 maja 2015 r. ${ }^{46}$

Zaledwie pół roku od wejścia w życie (w dniu 1 lipca 2015 r.) nowego modelu procesu karnego nowy rząd rozpoczął prace nad przywróceniem niektórych rozwiązań obowiązujących do 30 czerwca 2015 r. Projekt z dnia 8 stycznia 2016 r. ustawy o zmianie ustawy - Kodeks postępowania karnego oraz niektórych innych ustaw $^{47}$ zmodyfikował model procesu karnego ze wzmocnioną zasadą kontradyktoryjności na rzecz przywrócenia aktywniejszej roli sądu, co zdaniem autorów projektu ma zapewnić w maksymalnym stopniu zgodność ustaleń faktycznych z prawdą materialną oraz zwiększyć efektywność ścigania. Warto podkreślić, że projekt - co istotne - nie przewidywał zmian dotyczących kręgu osób uprawnionych do występowania w charakterze obrońców w postępowaniu karnym. Projekt w art. 1 pkt 12 i pkt 15 przewidywał jednak powrót do starych zasad wyznaczania obrońcy i pełnomocnika z urzędu, postulując uchylenie art. 80a oraz art. 87a k.p.k., zapewniających każdemu podejrzanemu obrońcę z urzędu lub stronie

${ }^{44}$ Pismo KRRP z dnia 5 sierpnia 2015 r. w sprawie zmiany rozporządzenia Ministra Sprawiedliwości z dnia 27 maja 2015 r. w sprawie sposobu zapewnienia oskarżonemu korzystania z pomocy obrońcy z urzędu; stanowisko KRRP z dnia 30 lipca 2015 r. w sprawie dalszych prac nad projektami rozporządzeń Ministra Sprawiedliwości w sprawie opłat za czynności radców prawnych oraz w sprawie ponoszenia przez Skarb Państwa kosztów nieopłaconej pomocy prawnej udzielonej przez radcę prawnego z urzędu.

${ }^{45}$ Uchwała Prezydium NRA nr 88/2015 z dnia 25 sierpnia 2015 r.

${ }^{46}$ Rozporządzenie Ministra Sprawiedliwości z dnia 22 października 2015 r. zmieniające rozporządzenie w sprawie sposobu zapewnienia oskarżonemu korzystania z pomocy obrońcy z urzędu (Dz.U. z 2015 r., nr 1787).

${ }^{47}$ Projekt ustawy o zmianie ustawy - Kodeks postępowania karnego oraz niektórych innych ustaw (druk sejmowy 207). 
niebędącej oskarżonym pełnomocnika z urzędu - na podstawie złożonego przez nich wniosku. W lutym 2016 r. Ośrodek Badań, Studiów i Legislacji KRRP przedstawił swoją, w dużej części krytyczną, opinię na temat proponowanych zmian, a podczas posiedzenia komisji uwagi do projektu zgłaszał ekspert Ośrodka. Sejm uchwalił jednak w dniu 11 marca 2016 r. ustawę w brzmieniu przewidującym uchylenie art. 80a oraz 87a k.p.k. ${ }^{48}$, zaś Senat nie wniósł poprawek. Ustawa została podpisana przez Prezydenta RP i weszła w życie w dniu 15 kwietnia 2016 r.

\section{BIBLIOGRAFIA}

Majewski J.M., Obrońcy art. 82 k.p.k., www.adwokatura.katowice.pl/z-naszej-izby-szczegoly/ items/obroncy-art-82-kpk.html [dostęp: 10.05.2016].

Opinia Ośrodka Badań, Studiów i Legislacji KRRP z dnia 2 lipca 2012 r.

Patyra S., Czy adwokat jest synonimem obrońcy, „Gazeta Prawna” 2015, http://prawo.gazetaprawna.pl/artykuly/911095,adwokat-synonimem-obroncy.html [dostęp: 10.06.2016].

Pismo KRRP z dnia 5 sierpnia 2015 r. w sprawie zmiany rozporządzenia Ministra Sprawiedliwości z dnia 27 maja 2015 r. w sprawie sposobu zapewnienia oskarżonemu korzystania z pomocy obrońcy z urzędu.

Pismo NRA z dnia 14 maja 2012 r. dotyczące projektu ustawy o zmianie ustawy - Kodeks postępowania karnego oraz niektórych innych ustaw.

Postanowienie TK z dnia 23 grudnia 2015 r., sygn. akt Tw 8/15.

Projekt rozporządzenia Ministra Sprawiedliwości w sprawie sposobu zapewnienia oskarżonemu korzystania z pomocy obrońcy z urzędu z dnia 28 stycznia 2015 r. (nr z wykazu A95).

Projekt ustawy o zmianie ustawy - Kodeks postępowania karnego oraz niektórych innych ustaw (druk sejmowy 207).

Rozporządzenie Ministra Sprawiedliwości z dnia 27 maja 2015 r. w sprawie sposobu zapewnienia oskarżonemu korzystania z pomocy obrońcy z urzędu (Dz.U. z 2015 r., nr 816).

Rozporządzenie Ministra Sprawiedliwości z dnia 22 października 2015 r. zmieniające rozporządzenie w sprawie sposobu zapewnienia oskarżonemu korzystania z pomocy obrońcy z urzędu (Dz.U. z 2015 r., nr 1787).

Rządowy projekt ustawy o zmianie ustawy - Kodeks karny oraz niektórych innych ustaw z dnia 15 maja 2014 r. (druk sejmowy nr 2393).

Rządowy projekt ustawy o zmianie ustawy - Kodeks postępowania karnego, ustawy - Kodeks karny i niektórych innych ustaw (druk sejmowy nr 870), www.sejm.gov.pl/sejm7.nsf/druk. $\mathrm{xsp}$ ?nr=870 [dostęp: 10.06.2016].

SN uchylit uchwaty dotyczace formy protestu Adwokatury, www.adwokatura.pl/z-zycia-nra/sn-uchylil-uchwaly-dotyczace-formy-protestu-adwokatury [dostęp: 14.06.2016].

Stanowisko KRRP do projektu rozporzadzenia Ministra Sprawiedliwości w sprawie opłat za czynności radców prawnych, http://kirp.pl/stanowisko-krrp-do-projektu-rozporzadzenia-ministra-sprawiedliwosci-w-sprawie-oplat-za-czynnosci-radcow-prawnych [dostęp: 14.06.2016].

Stanowisko KRRP z dnia 9 lutego 2015 r. dotyczące projektu rozporządzenia MS w sprawie sposobu zapewnienia oskarżonemu korzystania z pomocy obrońcy z urzędu, www.bibliotekakirp.pl/items/show/390 [dostęp: 15.05.2016].

${ }^{48}$ Ustawa z dnia 11 marca 2016 r. o zmianie ustawy - Kodeks postępowania karnego oraz niektórych innych ustaw. 
Stanowisko KRRP z dnia 30 lipca 2015 r. w sprawie dalszych prac nad projektami rozporządzeń Ministra Sprawiedliwości w sprawie opłat za czynności radców prawnych oraz w sprawie ponoszenia przez Skarb Państwa kosztów nieopłaconej pomocy prawnej udzielonej przez radcę prawnego z urzędu.

Światłowski A.R., Radca prawny jako obrońca $w$ postępowaniach $w$ sprawach o wykroczenia, „Radca Prawny” 2002, nr 2.

Uchwała Nadzwyczajnego Krajowego Zjazdu Radców Prawnych nr 1/2010 z dnia 27 lutego 2010 r. w sprawie stanowiska samorządu radców prawnych co do prowadzonych prac legislacyjnych dotyczących zawodów prawniczych.

Uchwała Prezydium NRA nr 88/2015 z dnia 25 sierpnia 2015 r.

Uchwała Senatu RP z dnia 20 września 2013 r. w sprawie ustawy o zmianie ustawy - Kodeks postępowania karnego oraz niektórych innych ustaw (druk sejmowy nr 1734).

Ustawa o zmianie ustawy - Kodeks karny oraz niektórych innych ustaw (Dz.U. z 2015 r., poz. 396).

Ustawa z dnia 20 maja 1971 r. - Kodeks postępowania w sprawach o wykroczenia (Dz.U., nr 12, poz. 116).

Ustawa z dnia 26 marca 1982 r. o Trybunale Stanu (Dz.U. z 2002 r., nr 101, poz. 925 ze zm.).

Ustawa z dnia 6 lipca 1982 r. o radcach prawnych (Dz.U., nr 19, poz. 145).

Ustawa z dnia 22 maja 1997 r. o zmianie ustawy - Prawo o adwokaturze, ustawy o radcach prawnych i niektórych innych ustaw (Dz.U. z 1997 r., nr 75, poz. 471).

Ustawa z dnia 6 czerwca 1997 r. - Kodeks postępowania karnego (Dz.U., nr 89, poz. 555).

Ustawa z dnia 10 września 1999 r. - Kodeks karny skarbowy (Dz.U., nr 83, poz. 930).

Ustawa z dnia 24 sierpnia 2001 r. - Kodeks postępowania w sprawach o wykroczenia (Dz.U., nr 106, poz. 1148).

Ustawa z dnia 10 stycznia 2003 r. o zmianie ustawy - Kodeks postępowania karnego, ustawy Przepisy wprowadzające Kodeks postępowania karnego, ustawy o świadku koronnym oraz ustawy o ochronie informacji niejawnych (Dz.U., nr 17, poz. 155).

Ustawa z dnia 30 czerwca 2005 r. o zmianie ustawy - Prawo o adwokaturze, ustawy o radcach prawnych i ustawy o notariacie (Dz.U., nr 163, poz. 1361).

Ustawa z dnia 28 lipca 2005 r. (Dz.U., nr 178, poz. 1479).

Ustawa z dnia 9 maja 2007 r. zmieniającej k.p.c. i inne niektóre ustawy (Dz.U., nr 121, poz. 831).

Ustawa z dnia 5 listopada 2009 r. o zmianie ustawy - Kodeks karny, ustawy - Kodeks postępowania karnego, ustawy - Kodeks karny wykonawczy, ustawy - Kodeks karny skarbowy oraz niektórych innych ustaw (Dz.U., nr 206, poz. 1589).

Ustawa z dnia 18 marca 2010 r. o zmianie ustawy o Trybunale Stanu (Dz.U., nr 75, poz. 472).

Ustawa z dnia 27 września 2013 r. o zmianie ustawy - Kodeks postępowania karnego oraz niektórych innych ustaw (Dz.U., nr 13, poz. 1247).

Ustawa z dnia 5 sierpnia 2015 r. o nieodpłatnej pomocy prawnej oraz edukacji prawnej (Dz.U. z 2015 r., poz. 1255).

Ustawa z dnia 11 marca 2016 r. o zmianie ustawy - Kodeks postępowania karnego oraz niektórych innych ustaw.

Uzasadnienie do projektu ustawy o zmianie ustawy - Kodeks postępowania karnego oraz niektórych innych ustaw (druk sejmowy nr 870), http://orka.sejm.gov.pl/Druki7ka.nsf/0/96832B0E D113D8FBC1257AB4004F3B04/\%24File/870.pdf [dostęp: 10.05.2016].

Wniosek NRA z dnia 22 kwietnia 2015 r. o zbadanie zgodności ustaw z Konstytucją RP, www.adwokatura.pl/admin/wgrane_pliki/file-trybunalnraradcyobrony-11446.pdf [dostęp: 14.05.2016].

Wyrok SN z dnia 5 listopada 2015 r., sygn. akt III ZS 9/15. 


\section{SUMMARY}

The status of legal counsel in a criminal procedure has been gradually changing over time. It was caused by political factors, and was connected with the necessity to overcome the reluctance of the Bar Association. Initially, a legal counsel could appear in a criminal trial as an attorney, although until 2009 this entitlement was limited to a defined group of represented bodies. The authority to defend was granted to legal counsels in misdemeanour cases in 2001, except for disciplinary proceedings. Greater governance in the powers of legal counsels and defence lawyers resulted in the Bill on the lawyer profession of 22 October 2009, which aimed at creating the so-called new Bar Association. However, the Bill was not passed because of critical attitude of both professional bodies. The Bill would have allowed a legal counsel to appear before a court as a defence lawyer in a criminal procedure. An attempt to resolve this issue was made during work on comprehensive amendments to the criminal-procedure law. This work began in 2012 and resulted in the Act of 27 September 2013 on Amending the Act - the Code of Criminal Procedure and other acts. Finally, legal counsels were granted the power to appear before a court in the capacity of a defence lawyer in a criminal procedure, excluding legal counsels working under employment contracts, apart from the researchers and academics. Attempts to question the aforementioned amendment by the Bar Association in the Constitutional Tribunal proved to be ineffective. The next amendment to the criminal-procedure law, passed in March 2016, restoring some of the provisions in force prior to the great reform of criminal trials, did not change the powers of legal counsels to appear before a court as defence lawyers in a criminal procedure.

Keywords: legal counsel; criminal procedure; attorney; plenipotentiary; legal assistance from the office 